\title{
Discurso da comunicação: encontro entre ficção e realidade
}

Maria Aparecida Baccega

Professora do mestrado da ESPM; coordenadora adjunta do Programa de Mestrado em Comunicação e práticas de consumo (ESPM); professora associada aposentada da ECA-USP; Editora da revista Comunicação \& Educação de 1994 a 2005; autora de artigos e livros, entre os quais: Comunicação e linguagem: discursos e ciência (Moderna) e Televisão e escola: uma mediação possivel? (Senac).

E-mail: mabga@usp.br

A principal mediação entre o homem e a realidade objetiva são as linguagens, destacando-se a verbal. A palavra, que carrega consigo um juízo de valor - bom/mau; certo/errado; bonito/feio -, constitui, portanto, a principal mediação.

O mundo que encontramos ao nascer é recortado e classificado pelas gerações que nos antecederam. E nosso pensamento, formado de fora (daqueles conceitos que estão circulando na sociedade) para dentro de cada um de nós, encontrará prontas não só as descrições, os recortes, como também - e, quem sabe, principalmente - os juízos de valor que obrigatoriamente os acompanham.

A linguagem verbal, alicerce no qual, predominantemente, se assenta a formação do sujeito, se, por um lado, manifesta a história daquela cultura, com seus mitos, estereótipos, valores - recortes e classificação-, permite que tais mitos sejam reelaborados, reconceituados a partir da práxis daquela cultura. É o que lembram Schaff ${ }^{1}$, Barthes ${ }^{2}$, Bakhtin ${ }^{3}$, entre muitos outros.

A complexidade da palavra, caracterizada pela polissemia, ou seja, a multiplicidade de sentidos atualizados nos diferentes discursos ou presentes no mesmo discurso, variando de acordo com as práticas culturais do receptor, manifesta-se mais claramente nas narrativas.

São as narrativas que constituem tanto a história, realidade, quanto a literatura, ficção. Tal inter-relação entre ficção e realidade, característica de todos os tempos, está presente nos meios de comunicação, através dos diferentes discursos dos variados gêneros midiáticos - da ficção ao noticiário, do esporte aos registros de violência. Em outras palavras: defendemos que o discurso da comunicação é a conjunção de dois discursos narrativos, ou seja, o da história e o da fiçã̃o.

Reflexões preliminares sobre essa temática é o objetivo deste artigo.

1. SCHAFF, Adam. Linguagem e conhecimento. Coimbra: Almedina, 1974.

2. BARTHES, Roland. Elementos de semiologia. São Paulo: Cultrix. 1971. p. 26-38; Aula. São Paulo: Cultrix, [s.d.]. p. 4-47.

3. BAKHTIN, Mikhail. Marxismo e filosofia da linguagem. São Paulo: Hucitec, 1988. 
comunicação \& educação • Ano XII • Número 3 • set/dez 2007

\section{O SUJEITO E O DISCURSO}

A importância da narrativa para a comunicação entre os homens, desde sempre, é indiscutível. Seu aproveitamento pelos meios de comunicação em geral é freqüente: dos tradicionais aos novos e novíssimos, sem falar do mais democrático deles, o aparelho fonador, que está presente em todos os seres humanos, e os caracterizam.

Ocorre que cada domínio - e aqui estamos destacando três deles: história, literatura, comunicação - apresenta-se ele próprio como uma totalidade aparentemente desvinculada das demais. A articulação entre todos os domínios por parte da sociedade é o percurso mais rápido para o conhecimento científico da realidade e sua mudança/transformação. Mas tem sido bastante dificultado.

Como diz Pêcheux, o sentido de uma palavra é sempre determinado pelas condições de produção e pelas diferentes posições ideológicas presentes no processo histórico de uma dada sociedade:

[...] as palavras, expressões, proposições etc. mudam de sentido segundo as posições sustentadas por aqueles que as empregam, o que quer dizer que elas adquirem seu sentido em referência a essas posições, isto é, em referência às formações ideológicas nas quais essas posições se inscrevem ${ }^{4}$.

Assim, os signos mudam de sentido e são escolhidos também de acordo com o domínio no qual circulam. Para Pêcheux, numa formação ideológica temos também o que pode e deve ser dito (articulado sob a forma de uma arenga, de um sermão, de um panfleto, de uma exposição, de um programa etc. $)^{5}$. É o que o autor chama de formação discursiva.

Estamos, portanto, considerando discursos da história, da literatura e da comunicação como discursos em que as mesmas palavras ganham sentidos próprios, diversos, dada a natureza de cada um e suas condições de produção. Esses discursos, como todos os demais, vão se desvelar na direção da reprodução ou da mudança, de acordo com o ponto de vista do sujeito que elabora tais discursos.

Esse sujeito é o historiador, o escritor, o comunicador.

4. PÊCHEUX, Michel. Semântica e discurso: uma crítica à afirmação do óbvio. Campinas, Editora da Unicamp, 1988. p. 160.

5. Ibid.

6. CERTEAU, Michel. A escrita da história. Rio de Janeiro: Forense Universitária, 1982. p. 45.

\section{Discurso da história}

O termo história, em português, tanto conota aquilo que se diz - o discurso - como aquilo que se passou ou está se passando - o fato. Em outras palavras: tanto a ciência, construída, quanto o objeto dessa ciência, o real. Como diz Certeau, o real é ao mesmo tempo o resultado da análise e seu postulado ${ }^{6}$.

E qual o material de que o historiador pode se servir para buscar, no presente, a totalidade do passado? Não é incomum ouvir-se, ainda, a afirmação segundo a qual à ciência histórica só interessam os textos escritos. O que é um equívoco, pois, desde as décadas de 1930 e 1940, todos os textos passaram a 
interessar os estudiosos de história. Lucien Febvre ${ }^{7}$, em Profissões de Fé à Partida, já revelava a estreiteza dessa afirmação, mostrando que, se assim fosse, se deixariam de lado as marcas do trabalho de todas as gerações, desde o momento em que os neolíticos humanizaram a terra, lavrando-a.

A história vai trabalhar com textos, sim, mas textos de todos os códigos, de todos os campos semiológicos, em cujo trânsito o homem, afinal, vive. São esses textos que possibilitarão ao homem reconstruir o passado a cada geração.

E Febvre explicita o sentido de ser historiador, do fazer história:

[...] a História faz-se com documentos escritos, sem dúvida, quando eles existem; mas ela pode fazer-se sem documentos escritos, se os não houver. Com tudo o que o engenho do historiador pode permitir-lhe utilizar para fabricar o seu mel, à falta das flores habituais. Portanto, com palavras. Com signos. Com paisagens e telhas. Com formas de cultivo e ervas daninhas. Com eclipses da Lua e cangas de bois. Com exames de pedras por geólogos e análises de espadas de metal por químicos. Numa palavra, com tudo aquilo que, pertencendo ao homem, depende do homem, serve o homem, exprime o homem, significa a presença, a atividade, os gostos e as maneiras de ser do homem ${ }^{8}$.

O estudo da história, portanto, não tem como objeto a relação de fatos históricos constituídos; mais que isso, deve preocupar-se em constituir os fatos históricos, ou seja, estudar a rede de relações que envolve determinado período, transformar os acontecimentos de fato em si em fato para nós.

Como diz Schaff,

[...] o historiador não parte dos fatos, mas dos materiais históricos, das fontes, no sentido mais extenso deste termo, com a ajuda dos quais constrói o que chamamos fatos históricos. Constrói-os na medida em que seleciona os materiais disponíveis em função de certo critério de valor, como na medida em que os articula, conferindo-lhes a forma de acontecimentos históricos. Assim, a despeito das aparências e das convicções correntes, os fatos históricos não são um ponto de partida, mas um fim, um resultado (grifo nosso) ${ }^{9}$.

O historiador é o pesquisador que se dedica a elaborar fatos e reconstruir o passado. Pratica um trabalho que se inscreve no interior das disputas socioeconômicas do seu tempo. Tem no documento - vazado em qualquer linguagem - a materialização de suas buscas. Resultado das articulações e inter-relações, seu discurso irá se manifestar, em geral, em código verbal. E a linguagem verbal, que foi suporte da formação do historiador, é aqui suporte do resultado do seu trabalho.

Muitas dessas características estão presentes no discurso da comunicação.

\section{Discurso da literatura}

Ao abordarmos o discurso da história, enfatizamos a relação do real com o historiador, mostrando o fato histórico como uma construção sua. Ou seja: a partir de suas escolhas, presas à sua cultura, elabora determinadas
7. FEBVRE, Lucien. Combate pela história. Lisboa: Presença, 1985. p. 17.

8. Ibid., p. 249.

9. SCHAFF, Adam. História e verdade. São Paulo: Martins Fontes, 1978. p. 307. 
articulações dos fatos (e não outras), selecionando com base no que ele considera de importância na contemporaneidade histórica e elaborando as articulações dos acontecimentos do passado a começar dela.

E o discurso da literatura? O que o distingue basicamente do discurso da história?

Poderíamos responder dizendo que o discurso da literatura prende-se à consciência estética. Se assim não fosse, o sujeito estaria fazendo história, e não romance.

No entanto, não basta dizer que o discurso literário é o resultado da relação entre a consciência estética e a realidade objetiva que a gerou, nem que é o entrelaçamento do sujeito esteticamente formado com a consciência social e individual. É preciso também verificar sua relação com o desenvolvimento do domínio a que pertence e com a concepção de literatura presente naquela sociedade, naquele momento.

Tomando o caráter lingüístico do pensamento conceptual como base, Schaff afirma que

[...] é evidente que a linguagem exerce uma ação, tanto na produção científica e técnica como na produção artística (principalmente na literatura, mas também na música e na pintura). Já constatamos que seria impossível exprimir e pensar a teoria da relatividade na língua de uma tribo primitiva australiana. Da mesma maneira que não seria possível realizar nela a música moderna (nem sequer a música de Bach) e a pintura moderna. Estas artes [...] são o produto de um pensamento conceptual altamente desenvolvido, que é irrealizável sem uma língua adequadamente formada ${ }^{10}$.

Fazer literatura permite ao artista se colocar certos problemas sobre a realidade que ele vive ou que lhe é relatada e responder artisticamente a esses problemas, sempre de acordo com seu ponto de vista, que o encaminhará para a inclusão de um outro problema, resolvendo-o artisticamente.

Em outras palavras: o sujeito do discurso literário não fabrica o material com que trabalha. Esse material existe independentemente dele e dele receberá uma dada ordenação. Essa ordenação tem implícita uma rede de relações que possibilitará que os fatos, ordenados, tenham um outro significado: o significado que lhe foi atribuído pelo artista, no romance.

Assim também acontece com a palavra, matéria-prima da literatura: o escritor não precisa criar outras palavras, diferentes das que circulam no cotidiano, para garantir a dimensão artística dessa matéria-prima; basta que ele teça, através delas, relações que configurem uma realidade nova - a do romance. Deslocando os fatos, mediante novas relações, e imprimindo às palavras, enquanto habitantes do romance, novos sentidos, o escritor produz uma outra verdade.

O discurso da literatura, como os demais discursos, possui especificidade. Ele constitui o rompimento com o que lhe é exterior, ao mesmo tempo em que esse rompimento, ao instituí-lo, distingue-o de tudo que o rodeia. É assim que constrói seus próprios limites. 
Desses limites, por outro lado, estende-se a ponte que o liga à realidade exterior a ele: elaborada a partir da linguagem verbal, que contém a prática daquela sociedade aí solidificada - ou, como dissemos, na qual se assenta a história daquela cultura -, a obra literária mantém estreitos laços com a sociedade que a concebeu. Ela é resultado do trabalho do escritor, homem do seu tempo e do seu espaço. Ela é o elo seguinte do domínio literário, ao qual deve suas possibilidades de elaboração.

\section{Semelhanças e diferenças: literatura e comunicação}

O escriturador do discurso, seja o discurso histórico, o literário, seja o da comunicação, é, portanto, aquele sujeito que toma a palavra, atualiza o código verbal (e a palavra só existe quando alguém a assume), renova os procedimentos discursivos para manifestar sua escolha dos fatos, respeitando as normas do domínio a que está filiado seu discurso: as da história, da literatura ou da comunicação. Ao tomar a palavra, o sujeito institui-se como criador/recriador, com todos os valores e estereótipos que lhe são próprios, inserindo-se no diálogo cultural de seu grupo social, no diálogo cultural da humanidade. Escolhe e rearranja os discursos existentes, dando-lhes outros significados.

Essas características são comuns aos três domínios. Ao mesmo tempo, há marcas que os diferenciam.

Assim, segundo Eagleton, a obra literária:

[...] está contida na ideologia, mas consegue também distanciar-se dela a um ponto em que nos permite "sentir" e "apreender" a ideologia de que nasceu. Ao fazê-lo, a arte não nos permite conhecer a verdade que a ideologia esconde, já que, para Althusser, "conhecimento" no sentido restrito significa conhecimento científico - o tipo de conhecimento, por exemplo, do capitalismo que nos é dado pelo $O$ Capital de Marx e não por Hard Times de Dickens. A diferença entre a ciência e a arte não consiste em tratarem objetos diferentes, mas sim em tratarem o mesmo objeto de diferentes maneiras. A ciência dá-nos um conhecimento conceptual de uma situação; a arte dá-nos a experiência dessa situação, o que é equivalente à ideologia. Mas, ao fazê-lo, permite-nos "ver" a natureza dessa ideologia e começa, assim, a conduzir-nos no sentido da compreensão plena da ideologia que é o conhecimento científico ${ }^{11}$.

Ou seja: cada um de nós inicia o percurso do universo ficcional de determinado modo; carrega seus valores, seus problemas, suas vivências. Esse universo ficcional, o qual nos possibilita viver as situações que apresenta através da emoção, permite que, após o percurso, estejamos mais aptos ao conhecimento científico da realidade em que vivemos.

As questões colocadas no discurso literário, tal qual no discurso da comunicação, são questões do cotidiano e a cada discurso compete, exatamente, elevar essas questões a um patamar superior. Ou seja, a comunicação sobreleva fatos, questões que devem ser divulgadas de acordo com interesses empresariais e de espetáculo; a literatura escolhe questões que, passando a
11. EAGLETON, Terry. Marxismo e crítica literária. Porto, Afrotamento, 1978. p. 31. 
existir agora no âmbito do romance, poderão destrinçar temas sociais. Assim a literatura faz o leitor ver que, aquilo que se apresenta como simples, nada mais é que a simplificação às vezes ingênua, às vezes inconsciente, às vezes manipulada da complexidade da totalidade. Sendo o discurso das possibilidades históricas, só o discurso literário poderá atingir esse objetivo, revelando o não-simples através de uma grande variedade de formas, muitas vezes contraditórias.

A literatura toma todos esses conteúdos quando ainda em formação. Tomaos no próprio cotidiano da sociedade, já marcados, evidentemente, pela carga valorativa - sem essa carga valorativa não haveria literatura, até porque não haveria palavra. Tal qual o discurso da comunicação e o discurso da história.

$\mathrm{Na}$ literatura estão presentes os discursos de todos os universos, inclusive os não-artísticos; por exemplo, fatos históricos, articulados no discurso da história. Mas, ao utilizar-se deles, ela não só os configura artisticamente, como dá a eles novas formas, produzindo novos significados, que circularão na obra literária. O mesmo faz o discurso da comunicação. Também se utiliza dos discursos de todos os universos, oferecendo-lhes novos significados, pautados por interesses de espetacularização e de concordância com as diretrizes da empresa.

\section{História e literatura: aproximações e distanciamentos}

O discurso não é apenas uma cadeia de enunciados, palavras ou frases que se justapõem. Ele tem que supor sempre o conjunto de relações sociais, contextuais que o constituem e que estão inscritos na palavra, matéria-prima de que ele se utiliza. Isso tanto vale para o discurso da história quanto para o discurso da ficção e também para o discurso da comunicação.

Cada um desses discursos está preso a certo domínio, a processos discursivos específicos: os discursos literários estão presos aos domínios literários da sociedade em que se instauram, e os discursos históricos, aos domínios do estudo da história daquela sociedade. O primeiro se prende à ficção, à consciência estética; o segundo, à ciência. Ou seja, o domínio a que pertence um ou outro discurso vai fornecer o corredor de sentido no qual ele deverá ser lido. $\mathrm{E}$ ambos os discursos aparecerão no discurso da comunicação.

Em outras palavras: o receptor não lerá um discurso que se denomina histórico como se fosse ficção. Embora haja inter-relação entre ambos, eles se distinguem: o discurso literário tem por objetivo a construção da realidade estética, ainda que para tal se utilize, como já dissemos, de outros discursos, mesmo científicos.

12. FREITAS, Maria Teresa de. Literatura e história: o romance de André Malraux. São Paulo: Atual, 1986. p. 42.
E a realidade estética significa problematização da realidade objetiva, seja ela qual for; a literatura visaria, então, não apenas colocar a presença das coisas, mas interrogar essa presença, a pô-la em questão; e uma das qualidades do texto literário está justamente na força desse questionamento ${ }^{12}$. 
Por outro lado, o discurso da história trabalha com signos já vividos, presentificados e incorporados, de algum modo, à vida social. E o que faz o historiador se não destacar tais signos, elaborar novas inter-relações, dando-lhes novo estatuto, novo sentido? E o que faz o ficcionista se não trabalhar também com signos estabelecidos em sua sociedade - dando-lhes novas conotações, produzindo com eles um outro universo - devolvendo-os ao receptor?

Logo, se nos limitássemos a uma análise apenas interna do texto, sem as relações com as condições de produção do discurso, estariam cortadas as relações deles com o processo histórico daquela sociedade, com o domínio ao qual pertencem e com a sua apropriação por parte do sujeito.

Barthes designa o discurso da história como o discurso do aconteceu, aquele que se caracteriza pelo efeito de real, cujo prestígio, diz ele, tem uma importância e uma amplitude verdadeiramente histórica. $\mathrm{O}$ "efeito de real é encontrado também no romance realista, diário íntimo, literatura de documento, noticiário policial, museu histórico, exposição de objetos antigos"13.

Diferentemente, a literatura não é o discurso do aconteceu, é o discurso do jogo de possibilidades; ela não busca o efeito de real, ela é o outro real.

Ainda segundo Barthes ${ }^{14}$, a idéia do real acompanha o discurso da história desde a Antigüidade. Opõe-se ao verossímil, que caracteriza a literatura. O real não resiste à narrativa de ficção, construída, por definição, sobre um modelo que, nas grandes linhas, outras injunções não têm senão as do inteligivel; mas esse mesmo "real" passa a ser a referência essencial da narrativa histórica, que pretende relatar "aquilo que se passou realmente".

Já o discurso histórico, como vimos, objetiva trazer o passado ao presente. Revive ou ressuscita o passado, procurando restaurá-lo através das marcas que deixou. Mas essa restauração do passado será feita mediante um discurso realizado no presente, por um homem do presente.

Ele será a imbricação do discurso do passado, do acontecido, com o discurso do presente, de quem relata.

E o que ocorre com o discurso literário? Segundo Milan Kundera, há que se distinguir dois tipos de romance: o que examina a dimensão histórica da existência humana e o que é a ilustração de uma situação histórica, "a descrição de uma sociedade num dado momento, uma historiografia romanceada" ${ }^{15}$.

Logo, quer seja num ou noutro caso, a história está presente no romance, cujo discurso é também o discurso produzido no presente sobre fatos ocorridos ou elaborados como ocorridos. No entanto, como diz Kundera, "a única razão de ser do romance é dizer aquilo que apenas o romance pode dizer"16. Segundo esse autor, a história entra nos romances com o que ele chama de economia máxima, ou seja, como um dos elementos de composição.

Então, o que temos como distinção entre o discurso histórico e o literário é o fato de que o efeito de real que entra no discurso histórico como parte integrante passa, no discurso literário, a ser o que Barthes ${ }^{17}$ chama de ilusão referencial, a qual consiste na volta do real à narração, agora a título de conotação. Ou seja, esses elementos, no discurso literário, passam a significar o outro real.
13. BARTHES, Roland. $O$ rumor da língua. São Paulo: Brasiliense, 1988. p. 156.

14. Ibid., p. 163.

15. KUNDERA, Milan. A arte do romance. Rio de Janeiro: Nova Fronteira, 1988. p. 36-38. Ensaio.

16. Ibid., p. 37.

17. BARTHES, O rumor da língua, op. cit., p. 164. 
18. BAKHTIN, op. cit., p. 124.

19. BARTHES, O rumor da língua, op. cit., p. 164.

20. LIPPMANN, Walter. Estereótipos. In: STEINBERG, Charles (Org.). Meios de comunicação de massa. São Paulo: Cultrix, 1970. p. 149-159.

21. BOSI, Eclea. O tempo vivo da memória. São Paulo: Ateliê, 2003.

22. SCHAFF, Adam. Ensayos sobre filosofia del lenguaje (Ensaios sobre filosofia da linguagem). Barcelona: Ariel, 1973.

23. HELLER, Agnes. O cotidiano e a história. São Paulo: Paz e Terra, 1989. comunicação \& educação • Ano XII • Número 3 • set/dez 2007

O discurso literário contém não os acontecimentos efetivamente vividos, mas o campo das possibilidades humanas, com base em uma dada realidade histórica: tanto a atual, na qual o escritor, inclusive, está inserido, como, a partir da atual, a visão das possibilidades humanas do passado. E é desse modo que a literatura possibilita ao homem uma reflexão sobre a realidade, um passo no caminho do conhecimento científico. Os discursos literários desenham o mapa da existência, e não o mapa da sociedade.

Por outro lado, o discurso histórico vai contar os fatos que o historiador tem como importantes, isto é, que se distinguem, aos olhos do historiador, de todos os demais da mesma época. Assim fazendo, tais fatos tornam-se notáveis, na expressão de Barthes, dando prestígio a determinados aspectos, a determinadas leituras daquela época.

Nesse sentido, a história vai caminhar imbricando em seu discurso tanto a elucidação de sua própria atividade produtiva como a sua inserção no conjunto e na sucessão de produções das quais ela própria é um efeito.

Assim também é o discurso literário. Alimenta-se não só dos outros discursos literários daquela dada sociedade, bem como dos discursos históricos e de outros discursos, verbais e não-verbais. Estabelece-se um verdadeiro diálogo entre os discursos.

Não é possível isolar a comunicação verbal, os discursos, os domínios, desse diálogo ininterrupto que constitui a vida social. E, nesse diálogo, os procedimentos discursivos passam a ter significações específicas: "Os elos que se estabelecem com os diferentes elementos de uma situação de comunicação artística diferem dos de uma comunicação científica" ${ }^{18}$.

Logo, os discursos da história e da ficção possuem aproximações e distanciamentos.

Na história o homem existe e a literatura é o discurso da existência humana, das suas várias possibilidades. A história é o desdobramento no tempo dessas diversas possibilidades. O homem é personagem, que é homem. E o escritor é o criador de personagens que se incorporarão em homens.

\section{Discurso da comunicação: encontro da história e da literatura}

Os meios de comunicação ocupam lugar de destaque nas sociedades contemporâneas. O discurso da comunicação, que também toma o cotidiano como matéria-prima, resulta tanto do aconteceu (discurso da história) quanto do jogo de possibilidades (discurso literário). Ele carrega não só o efeito de real, mas até mesmo o outro real, a ilusão referencial ${ }^{19}$. Nenhum discurso da comunicação está neste ou naquele pólo desse pêndulo, porém vai se revestir sempre de características predominantes a um ou outro.

Isso porque um número incalculável de fatos e acontecimentos ocorrem a todo momento. Como lembram Lippmann ${ }^{20}$, Bosi ${ }^{21}$, Schaff ${ }^{22}$ e Heller ${ }^{23}$, vivemos e experimentamos diretamente um número extremamente reduzido desses 
fatos, desses acontecimentos. E mesmo os que vivemos, apreendemos sempre com as mediações que nos são inculcadas, sobretudo, pela linguagem verbal. Os outros fatos e acontecimentos nos chegam através de relatos, quer de pessoas que deles participaram, quer - e principalmente - por meio dos veículos de comunicação (tradicionais, novos ou novíssimos), que introduzem suas próprias mediações: desde as do profissional presente ao fato, até aquelas condicionadas aos interesses político-sociais da própria empresa ${ }^{24}$.

Os profissionais de comunicação, em especial os jornalistas, têm a fé pública, ou seja, a sociedade confere-lhes a competência de representá-la diante do real, isto é, assistir ao acontecido e, depois, relatar-lhe.

Ocorre que, apesar das mediações que existem no ato de narrar, em geral as pessoas consideram que têm uma visão objetiva do mundo, a partir de tais relatos. Essa visão objetiva nada mais é que a visão generalizada em uma dada sociedade, sendo considerada, por isso, natural. Em outras palavras: essa visão monossêmica do mundo, como se fosse possível que os fatos relatados só tivessem uma interpretação, um sentido, é bastante equivocada. Esse conhecimento do mundo resulta da seleção dos fatos a serem divulgados e do ponto de vista sobre eles, explícita ou implícita no relato, o qual chegou até nós depois de passar por um sem-número de mediações. Insista-se que essa seleção se inicia na opção por relatar determinado fato em detrimento de todos os outros fatos acontecidos.

Para persuadir o receptor, utiliza-se de uma maneira própria de estruturar o texto: é escrito em terceira pessoa, como se o fato assumisse contar-se a si mesmo, sem qualquer intermediação do sujeito e de sua linguagem. Quando o texto deixa entrever seu autor, é considerado subjetivo e passa a ser menos digno de fé, até mesmo falso. Salvo, no caso da imprensa, se ele estiver no espaço do editorial ou em matéria assinada.

A narrativa muitas vezes é encenada. Por exemplo, o jornalista transformase em ator, ensaiando as perguntas e respostas antes da gravação para a TV. Nessas encenações, até os entrevistados fazem parte da produção. Ou ainda: quando algum grupo se encontra numa manifestação e se aproxima a televisão para captar imagens, os próprios manifestantes agem de modo diferente, agitam-se mais para aparecer na televisão. É a introjeção da condição de atores na produção televisiva, que fala mais alto do que a condição de atores do processo histórico.

Os produtos colocados ao alcance da população são, portanto, alguns recortes do processo histórico, para que ela os leia como se constituíssem o processo histórico todo. Trata-se de um processo metonímico - a parte pelo todo -, o qual nos oferece pronta a edição do mundo, como a única realidade à qual temos acesso. É a partir dos meios de comunicação que o mundo passa a ter sentido. O mundo todo é aquele: o editado para nós.

Se buscarmos a manifestação textual, podemos perceber algumas aproximações entre os discursos da história e da comunicação: ambos são referenciais. Procuram fazer desaparecer o sujeito através de mecanismos lingüísticos, como enunciado em terceira pessoa, como já dissemos, o não-uso de figuras de lin-
24. Ver Apropriações melodramáticas: o caso Pedrinho no Jornal $\mathrm{Na}$ cional e em Senhora do Destino. SOUSA JR., Walter de. Comunicação \& Educação. São Paulo: CCA-ECA-USP/Paulinas, n. 2, maio/ago. 2006. (N.E.) 
guagem etc. Desse modo, procuram sobrelevar o fato e não o ponto de vista (embora essa postura já revele um ponto de vista).

Tanto o discurso da história quanto o da comunicação constituem um texto a partir de uma pluralidade de vozes, das quais ou farão uma síntese, em que o sujeito obrigatoriamente assume a palavra, ou permitirão que cada uma permaneça, como se isso bastasse para configurar a presença de vários pontos de vista, a polifonia, também tão cara à literatura.

De todo modo, ambos os discursos organizam as vozes, dando prioridade a umas em detrimento de outras. E o próprio modo de organizar implicará sentidos diferentes aos discursos construídos. Voltamos, portanto, ao papel que desempenha o sujeito, tanto o comunicador quanto o historiador.

\section{O TEMPO DA COMUNICAÇÃO}

Tal qual o sujeito do discurso da literatura, o sujeito comunicador trabalha com o cotidiano. Também ele terá de possuir sensibilidade para desvelar o aspecto cambiante da palavra, assumindo, desse modo, seu papel de mudança.

Mas, para assumir esse papel de mudança, o sujeito comunicador precisa ter o sentido da totalidade, necessita conhecer o passado, deve saber elaborar/ reelaborar essas duas realidades conjunta e dialeticamente. $\mathrm{E}$ isso o difere do escritor e do historiador. Se o primeiro - o escritor - trabalha com o cotidiano, do presente ou do passado, a partir do qual cria seu universo e nele faz circular seus personagens, o segundo - o historiador - ocupa-se do passado, reelaborando-o cientificamente com base no presente. Ao comunicador competem as duas operações conjuntamente. Sem dúvida, a exigência é maior.

O comunicador é criador de novas realidades. Assim também o historiador e o escritor. Mas as novas realidades que o comunicador cria têm público imediato. Elas já estarão hoje ou amanhã nos jornais, na televisão, no rádio, na internet etc. Tanto no discurso histórico quanto no literário, o sujeito tem tempo para checar, rever, burilar ou até reescrever; no da comunicação, não - o fato é colhido no calor da emoção e o texto redigido na velocidade que o mercado consumidor exige. Os dois primeiros discursos são produtos de estudo e/ou reflexão de longa duração, enquanto o jornalístico é destinado, aparentemente, à breve vida que intermedeia uma edição da outra. São discursos, portanto, cujo conteúdo de realidade é apropriado obrigatoriamente de formas diferentes e que possuem registros igualmente diversos. Já no momento da produção o sujeito comunicador terá de revelar, portanto, uma criticidade bem desenvolvida. Precisará saber usar a palavra enquanto mediação, no sentido de ser dono dela, ser senhor de seu discurso, e não deixar-se falar por ela. No momento em que se deixa falar por ela, como acontece, ele perde sua condição de sujeito, capaz de construir, de recriar realidades.

O sujeito comunicador necessita saber que, sendo senhor da palavra, o produto de sua elaboração vai no sentido da desalienação do outro. 
Febvre $^{25}$ dizia que, para o estudo da história, devem se utilizar os textos, mas todos os textos, não apenas aqueles que estão escritos e que se oferecem nos arquivos à curiosidade do historiador. Textos de todos os campos semiológicos, longos ou curtos, feitos para permanecer ou estruturados nos desvãos do poder e do estabelecido. Assim também o comunicador, em especial o jornalista. Fontes, sim, mas todas as fontes, não apenas aquelas das agências, das entrevistas realizadas aparentemente como espetáculos produzidos; também as fontes presentes na realidade viva, dinâmica, feita de contradições. A realidade contemporânea, sim, e até mesmo o processo cristalizado nas práticas sociais e, sobretudo, na palavra.

Não ignoramos as pressões a que são submetidos os profissionais da comunicação: é a empresa (e é tão mais fácil ser a voz do dono que o dono da voz), são os grupos de fora da empresa, que se estruturam para pressionar; é a publicidade da qual, em geral, depende uma empresa de comunicação e cuja conta será cortada se a matéria for desabonadora a seu ramo de negócio; é a família que tem que sustentar e, por isso, o profissional depende do seu emprego. Mas todas essas situações, com características diversas, são vividas também pelos sujeitos dos outros discursos, não só os da comunicação. Na raiz dessa questão estão os objetivos de vida em que se coloca o sujeito; e, sejam quais forem, devem ser conscientes.

Tal qual o discurso literário, o discurso da comunicação será a confluência de todos os discursos sociais. Para tanto, o sujeito comunicador há que saber ler esses discursos sociais, sobretudo os discursos da história e da literatura, fontes nas quais deve banhar-se permanentemente. A história vai possibilitarlhe condições para o rearranjo do passado, que estará forçosamente presente no seu texto; a literatura irá lhe dar condições de melhor aproximar-se das emoções que fervilham na existência humana e que o conduzirão no caminho da descoberta das possibilidades históricas.

O que estamos propondo, enfim, é que o discurso do comunicador seja a conjunção dos discursos históricos e literários, com especificidades das quais os manuais de redação jamais darão conta.

Se, como colocamos, o cotidiano é a matéria-prima de que se servem o escritor e o comunicador, é preciso registrar a diferença: a literatura cria seus personagens, que só vivem no domínio do romance; o escritor conhece todas as ações, reações, processos e caminhos que as personagens percorrem em suas vidas. Já o comunicador trabalha com seres que têm nome e sobrenome, que se destacam no cotidiano por ações, reações ou resultados de processos que nem sempre o comunicador conhece e que ele não pode criar. Por isso se diz que a linguagem da comunicação é referencial e a da literatura, imagética. Ou, melhor dizendo, cada uma delas tem predominantemente tal característica. Diríamos nós que cada um dos discursos guarda a presença das duas características, uma vez que, existindo as mediações, ficção e realidade andam sempre juntas. Já com relação ao discurso da história, diríamos que, se é verdade que ele é mais referencial com relação à literatura, é também o resultado de uma análise feita pelo sujeito historiador. E aí reside a diferença. Essa análise é a que, no discurso da comunicação, vai ser feita pelo sujeito comunicador. Ele
25. FEBVRE, Lucien. Combate pela história. Lisboa: Presença, 1985 
não reproduz a análise da história, mas elabora as análises e vai construindo a história.

Tanto o discurso da história quanto o discurso literário servem ao comunicador como resultados de caminhos percorridos por outros sujeitos que, de modo diverso, souberam se acercar da realidade. Se o primeiro dá ao jornalista condição de perceber o processo histórico presente no cotidiano, onde está a gestar-se o futuro, o discurso da literatura vai lhe permitir conhecer novos modos de manifestação verbal, que assinalarão com maior rigor a captação dos seres, enquanto indivíduos; que possibilitarão ao comunicador acercar-se da realidade imediata com a percepção de quem consegue transfigurá-la no tempo, vendo nela o presente e o futuro.

Resumo: Além de focalizar as relações entre ficção e realidade, presentes na mídia, este artigo procura revelar as raízes dessa inter-relação, desse território enfumaçado que se tornaram as fronteiras entre ambos. Para tanto, trabalha questões relacionadas aos discursos. Privilegiando o signo verbal, a autora primeiramente localiza as premissas teóricas a partir das quais se darão as reflexões. São apresentadas a constituição e as características dos discursos da história e da literatura e, a partir delas, as semelhanças e diferenças entre comunicação e literatura. Desse modo, abre-se caminho para se pensarem propriamente as aproximações e distanciamentos entre os discursos da história e da literatura para, ao final, clarear-se a defesa da proposição da autora: o discurso da comunicação como encontro entre história e literatura, base da dissolução das fronteiras entre ficção e realidade na mídia.

Palavras-chave: linguagem, ficção e realidade, discurso, mediação, comunicação e literatura.
Abstract: Besides focusing relationships between fiction and reality present in media, this article proposes revealing that interrelationship's roots, of the undelimited area that their mutual borders have become. For that, it discusses speech-related issues. Privileging the verbal signal, the author first puts the theoretical premises for her reflections. She presents the constitution and characteristics of the History and Literary speeches and, from them, the similarities and differences between Communication and Literature. Thus, it is opened a path to think the proximities and distances between the speeches of History and Literature to, eventually, make clear the author's proposition: the Communication speech as meeting between History and Literature, basis of dissolution of the borders between fiction and reality in media.

Keywords: language, fiction and reality, speech, mediation, communication and literature. 